\title{
How store brands build retailer brand image
}

\author{
Florence KREMER (*) • Catherine VIOT (**) \\ (*) University of Bordeaux \\ Pôle Universitaire de Sciences de Gestion \\ 35, Avenue Abadie \\ France - 33000 BORDEAUX \\ Tel.: $33(0) 556009726$ \\ Fax: 0556009729 \\ e-mail address: kremer@u-bordeaux4.fr \\ (**) University of Bordeaux - IAE \\ Pôle Universitaire de Sciences de Gestion \\ 35, Avenue Abadie \\ France - 330000 BORDEAUX \\ Tel.: $33(0556009705$ \\ e-mail address: viot@u-bordeaux4.fr
}

\begin{abstract}
About the authors
Florence Kremer is Associate Professor of Marketing at University of Bordeaux where she teaches marketing, retailing and entrepreneurship. As head of a program that trains retail managers, she works in partnership with 10 major French retailers. Her research focuses on relationships between producers and retailers and store brands. She is member of the team of research in marketing of IRGO (Institut de Rercherche en Gestion des Organisations) - Bordeaux University. Florence Kremer is the corresponding author and can be contacted at: kremer@u-bordeaux4.fr.

Catherine Viot teaches courses in web marketing, wine marketing and marketing strategy. She is Associate Professor of Marketing at IAE (Institut d'Administration des Entreprises) de Bordeaux. She is member of the team of research in marketing of IRGO (Institut de Rercherche en Gestion des Organisations) - Bordeaux University. Her research focuses on strategic brand management, brand identity, brand personality, web marketing and wine marketing. Her research has been published in International Journal of Wine Business Research, Journal of Product \& Brand Management...
\end{abstract}

Kremer F., Viot C. (2012), How store brands build retailer brand image. International Journal of Retail and Distribution Management, Emerald, 40 (7), pp.528-543. 〈10.1108/09590551211239846〉 . 


\title{
How store brands build retailer brand image
}

\begin{abstract}
Purpose - The purpose of this research is to highlight the role store brands can play in retail branding. Does an image transfer take place between store brands and the retailer brand? To address this issue, we propose to identify and test the dimensions of image transfer from the store brand to the retailer brand.
\end{abstract}

Methodology - A qualitative study of 138 consumers helped us to complete the attributes of store brand image and retailer brand image identified in the literature. 322 customers of three major French retailers responded to a questionnaire. The data collected was tested in a structural equation model.

Findings - Results indicate that store brands have a positive impact on the retailer image. The price image of the store brand is positively related to the retailer price image. The values that customers associated with store brands improve the retailer brand image in terms of its values.

Research limitations - Store brands are considered as a whole, without distinction between product categories. We focus on standard store brands only, excluding 'premium' store brands.

Practical implications - Retailers can find a rationale for investing in their store brand range in order to differentiate themselves from their competitors. Managers should ensure that their store brands' image is seen as congruent with their own retailer brand image. In particular, more attention should be paid to the values reflected by the store brands and the store brands' price image.

Originality - Our results indicate that store brands not only benefit from the strength of the retailer brand. They also contribute, in a reciprocal way, to the improvement of the retailer image.

Key Words Store brands, Retailing, Brand Image, Retail Brand Equity.

Paper type Research paper 


\section{Introduction and purpose}

Both in Europe and the United States, retailers have made large investments to launch store brands, with the primary objective of securing significant financial benefits. Indeed, since the 1990's, store brands have been well-known for generating higher margins than national brands (Hoch and Banerji, 1993). They also give the retailer negotiating leverage over the manufacturers of the national brands they compete with (Scott-Morton and Zettelmeyer, 2004) and may enhance store loyalty (Corstjens and Lal, 2000; Binninger, 2008).

More recently, retailers have become aware of a new advantage: beyond their immediate profitability, store brands could also play a role in the process of positioning the retailer's shop formula as a brand (Steenkamp et al, 2004; Luijten and Reijnders, 2009). Also known as 'private labels' or 'own brands', store brands are exclusive to the retailer chain. Thus, they are associated with the retailer in a unique way, especially when they share the same brand name. Moreover, retailing at $30 \%$ less than the leading national brands ${ }^{1}$, store brands of equivalent quality $^{2}$ should improve retailer price image, by offering consumers good 'value for money'. Significantly, Carrefour, the second-largest world retailer, chose to use store brands in its first campaign on French TV in 2008 by displaying its own fishing products and baby diapers rather than the national brands it carries. Such an advertisement is obviously product-oriented as it positions Carrefour store brands as affordable and good-quality products. However, as the retailer and its store brands share the same brand name, we can wonder if promoting store brands does not also aim at improving the retailer's brand equity, at the chain level.

This relates to retail branding, an issue that has recently garnered greater attention from researchers (Burt and Sparks, 2002; Ailawadi and Keller, 2004; Kumar and Steenkamp, 2007, Burt and Davies, 2010). Retail branding conceptualization has evolved from an initial narrow focus on products only -namely the store brands- to a wider perspective that takes into account the store and the corporate dimensions of the retailer brand (Burt and Davies, 2010). Here we link these approaches by questioning the relationship between the store brands'image and the retailer image (defined here at the chain level and not at the store level). Simply, do store brands improve the perception of retailer brands?

\footnotetext{
${ }^{1}$ Price gap between standard store brands and branded manufacturing goods varies from about $25 \%$ (in Italy, Germany, The Netherlands) to $43 \%$ in Spain. It reaches $31 \%$ in the US and $35 \%$ in France. Yet, price gap also varies across retailers, product categories and store brand type (generic, standard or premium store brands). Source: Store brands special Report: U.S. \& Europe Store Brands Trends, SymphonyIRI Group, 2010.

2 "Store brands are as good quality as manufacturing goods" for $63 \%$ of consumers in France, $68 \%$ in Germany and $67 \%$ in the Netherlands. Source: Bord Bia Periscope, 2008.
} 
The main purpose of this research is to highlight the role that store brands play in retailer brand building and show whether a transfer of image takes place between store brands and the retailer brand or not. We propose to address this issue with a three-fold approach.

- The first objective is to identify the main dimensions of store brands' image and the retailer brand image: what are the dimensions of store brands' image and the dimensions of the retailer's image?

- The second objective aims to verify if a transfer of image really does take place between the store brands' image and the retailer brand image. In other words, do well-evaluated store brands reinforce the retailer image? And inversely, do poorly-evaluated store brands weaken the retailer image?

- Finally, if it turns out that an image transfer between store brands and the retailer brand does take place, then it is necessary to investigate the way this transfer occurs: what dimensions of store brands' image influence the retailer brand image? This forms the third objective.

The impact of store brands' image on retailer loyalty constitutes a more secondary focus of this research.

From a theoretical standpoint, our research echoes Ailawadi and Keller's (2004) call for deeper insight into the relationship between retail brand equity and the product assortment. Burt and Davies (2010) remind us that prior research focused mainly on the opposite relationship: by questioning the role the retailer - or, more often, the store - plays in the perception of store brands (Richarsdon et al, 1996a; Collin-Dodds and lindley, 2003; Semeijn et al, 2004; Vahie and Paswan, 2006; Ailawadi and Keller (2004)). They also underline, following Ailawadi and Keller (2004), that there is still a need for better comprehension of the role of store brands in building retailer equity. Thus our approach is relatively new and responds to an actual concern in retail research.

The expected implications of this study are important: retailers have developed store brands in almost every product category, and their economic prominence is constantly increasing. US store brands increased their unit share and dollar share in 2009 to $21.8 \%$ and $17 \%$ respectively ${ }^{3}$. In Europe, the unit share of average store brands is even higher, varying between $17 \%$ for Italy and over $50 \%$ for Switzerland ${ }^{4}$. What return on investment can retailers expect from their store brands, from a brand-equity standpoint? Can store brands be

\footnotetext{
${ }^{3}$ Source: the Nielsen Company in « The Future of US Store Brands », L. Rider, Food technology, 03.2010, 32 37.

${ }^{4}$ Source: the Nielsen Company for PMLA 2010.
} 
used as a brand-equity lever to accentuate retail differentiation, and generate more store loyalty?

The theoretical background of the research, anchored in brand extension theory, is presented first. The "dimensions" scope of both the store brand image and the retailer brand image is then identified, via the literature and a qualitative study, so as to propose a model that relates the dimensions of retailer brand image, as dependent variables, to dimensions of the store brand image, as explicative variables. Testing of the model is followed by an analysis of results and discussion.

\section{Theoretical framework}

The impact of retailer brand on store brands

The role played by the store image in the evaluation of the different retailed brands was originally explored by Jacoby and Mazursky (1984). In the retail sector, it is now wellestablished that a retailer with a favourable image improves the image of the store brands it carries by sharing its brand name with them (Burt and Sparks, 2002). Further results demonstrate that the retailer image or the store image helps fuel attitudes towards store brands (Richardson et al., 1996; Semeijn et al, 2004; Vahie and Paswan, 2006). Consumers use cues such as the physical environment of the store (Richardson et al, 1996), the composition and the display of the assortment or the level of service (Semeijn et al, 2004) to build a general belief about the retailer that, in turn, determines the attitude towards store brands. Previous concerns about how retailers influenced store brands can easily be explained by the anteriority of retail brands over store brands. When store brands were first introduced, they needed support from the retailer to be accepted by consumers as reliable products. This focus on how retailers assisted in the positioning of store brands also provides insight into cases of store brands that have been extended into unusual product categories. As Schwu-Ing and Jui-Ho (2010) show in the Taiwanese market, store image, store loyalty and store satisfaction have a positive and direct influence on the acceptance of store brand extensions. These studies, however, do not mention a potentially reciprocal effect from the store brands to the retailer image.

\section{A reciprocal effect from store brands to the retailer brand?}

The impact of a branded product on store image has been investigated in previous experimental studies: poor-image retailers may improve their image by being associated with a strong brand image; inversely, poor-image brands reduce a retailer's high quality image 
(Jacoby and Mazursky, 1984; Pettijohn et al, 1992). Those studies, however, focused on national brands only and not on store brands.

To our knowledge, only three papers have explicitly questioned the transfer of image from store brands to their retailer (Dimitriadis, 1993; Collins-Dodds and Lindley, 2003; Martenson, 2007). In a qualitative study, Dimitriadis (1993) underlined a discrepancy between retailers' expectations of store brands and consumers' perceptions of them. Whereas the retailers interviewed acknowledge that they expect store brands to deliver a better image in terms of price and choice for their chain, the respondents only see a downward relationship from the retailer to the store brands. The inverse relationship, from the store brands back up to the retail brand, does not make sense to consumers. In a quantitative study, Collins-Dodd and Lindley (2003) highlighted a positive relationship between consumers' perceptions of an individual store's own-brands and the image dimensions of the associated store. However, the regression analysis does not allow clarification of the way the relationship works. Martenson (2007) goes further by showing, in a structural equation model, that store brands contribute positively but weakly to the building of the corporate image of the retailer. And yet, no link between the store brands and the retailer as a brand, at the chain level, is taken into account. More cues for exploring the relationship between store brands and retailer brands can be found in the brand extension literature. Brand extension consists of using an established brand to penetrate a new product category (Tauber, 1981). Thus, a store brand can be analyzed as a brand extension of the retailer brand insofar as the retailer's brand name is explicitly mentioned on the packaging of the product it sells (Collins-Dodd and Lindley, 2003). Such a strategy is supposed to improve brand equity. More than developing a new brand, a firm chooses to extend its brand portfolio to a new product in order to benefit from the favourable image and awareness of a well-established brand (Aaker, 1990). Brand extension thus enhances the transfer of attitude towards the new product and limits the costs associated with the creation and the launching of a new brand (Boush et al, 1987; Keller and Aaker, 1992; McInnis and Nakamoto, 1990; Park et al, 1991). The authors define as the 'reciprocity effect' a change that appears in the consumer's initial attitude towards the parent brand after such an extension (Park et al, 1993). A brand extension introduces a new set of attributes and beliefs that is perceived as either congruent or not congruent with the brand image. So, a brand extension may either reinforce or dilute brand equity. When applied to the store brands, this theory suggests that store brands do potentially affect retail brands.

\section{Model conception}




\section{Retailer brand image and store brand image}

Here, we build a model where the retail brand image depends on the image of store brands. The retailer's brand image is considered to be multi-dimensional, according to a literature that often mixes associations related to the store or to the corporate image of the retailer, such as price (Birtwistle et al, 1999 ; Collins-Dodd and Lindley, 2003 ; Chowdury et al, 1998 ; Martenson, 2007), quality and variety of the assortment (Birtwistle et al, 1999; Collins-Dodd and Lindley, 2003 ; Chowdury et al, 1998; Gupta and Pirsh, 2008; Martenson, 2007; Mazursky and Jacoby, 1986), values, reputation, social responsibility (Birtwistle et al, 1999; Gupta and Pirsh, 2008), store atmosphere (Chowdury et al, 1998; Martenson, 2007; Mazursky and Jacoby, 1986) and quality of customer service (Birtwistle et al, 1999; Collins-Dodd and Lindley, 2003; Gupta and Pirsh, 2008). Since our concern is the retailer's brand image at the chain level rather than in a specific store, we completed our survey of the literature on retailer/store image with our own qualitative study. 138 consumers of five major French retailers (Auchan, Carrefour, E.Leclerc, Casino and Carrefour Market) were asked to give their opinion on the store brands, the retailer as a brand and the potential contribution of store brands to retailer brands. Store brands were considered as a whole. We do not investigate the impact of a specific store brand on a specific retailer brand but rather how store brands in general affect retailers' brands, irrespective of the product category. Moreover, we verified that the retailer's brand image could not be confused with store image, as, for the same chain, respondents tended to visit different stores.

\section{Proposition of a model with transfer effects}

In our proposed conceptual model, store brand image includes three dimensions that stem from the literature review and from our own qualitative study: price, supply and values. The price dimension refers to low prices, good deals and value for money. The supply dimension relates to the perceived quality of store brands, packaging, innovation and to the possibility of customers arbitrating between national brands and store brands. The third and final dimension harnesses values such as proximity, affordability, convenience and sustainability. Retailer brand image presents a comparable structure (Figure 1). 
Figure 1. - Conceptual model of image transfer from store brands to retailer brand

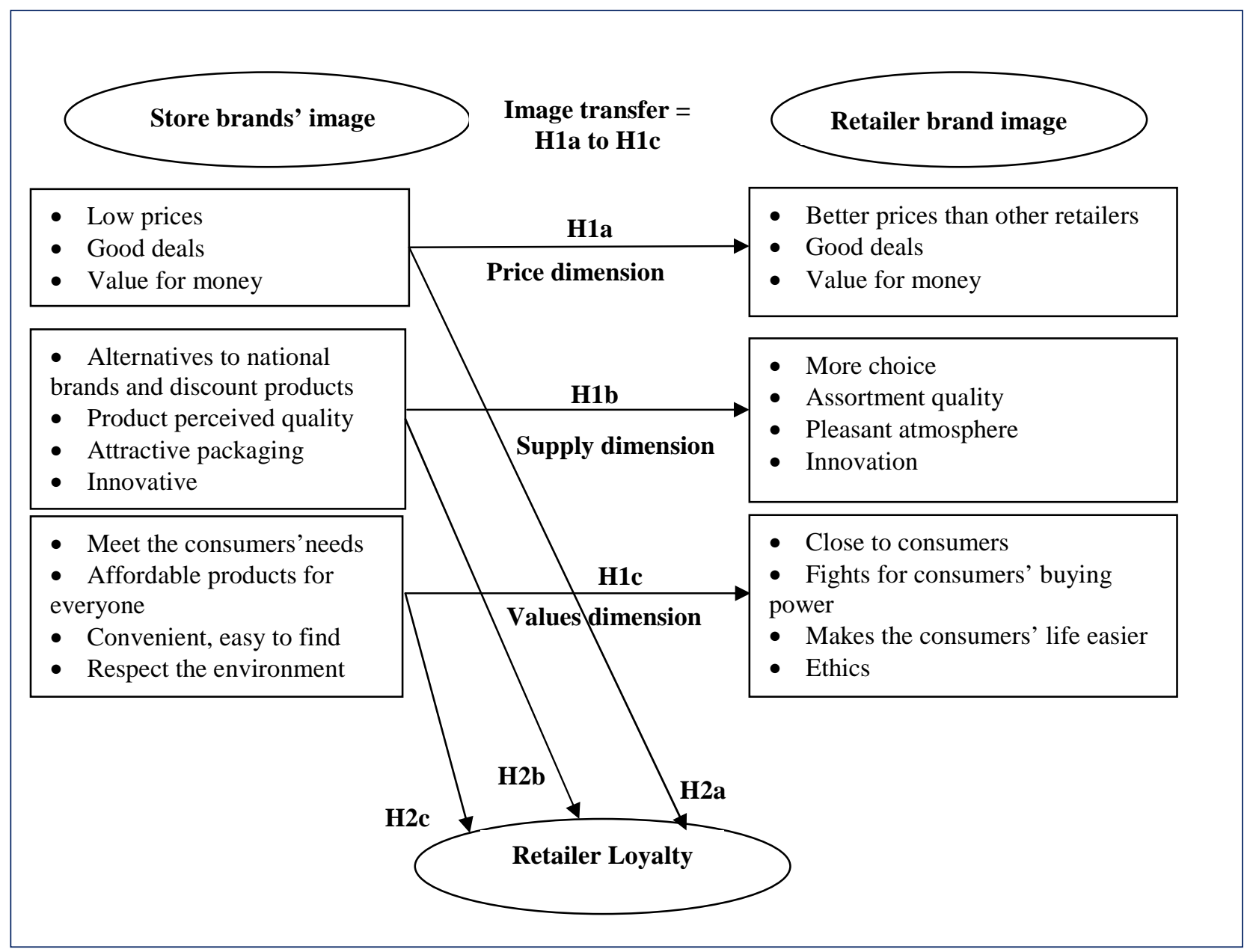

Following Collins-Dodd and Lindley (2002) who transposed the literature on brand extension into the context of store brands, we hypothesized that an image transfer from the store brand to the retailer occurs according the three dimensions identified.

The first transfer takes place between the store brand and the retailer's image on price. It suggests that competitive, low-priced store brands reinforce the retailer's image of competitiveness and its ability to provide good value for money.

The second transfer concerns the 'supply' dimension. Our qualitative study suggested that a range of store brands that is attractive in both quality and variety, with appealing packaging and innovative products, reinforces the perception that the retailer is providing its customers with a wide array of good products in a pleasant shopping environment.

A final transfer of image takes place regarding the values dimension: the values conveyed by store brands may strengthen the retailer image. Indeed, many of the respondents we interviewed associate store brands with positive values that bring them closer to consumers. 
We suggest here that these values could be congruent with the retailer's own values and help develop a retailer image associated with proximity, buying-power protection, convenience and even ethics.

Our purpose is to test whether and to what extent retailer image is simultaneously influenced by store brand image in these three dimensions. H1(a), H1(b) and H1(c) summarize the theoretical relationships:

H1 - There is a positive association between store brand and retail brand on all dimensions:

$$
\begin{aligned}
& \text { H1 (a) - price dimension; } \\
& \text { H1 (b) - supply dimension; } \\
& \text { H1(c) - values dimension. }
\end{aligned}
$$

For instance, H1(a) means that a good price image for the store brand improves the retailer price image. Inversely, a poor price image for store brands damages the retailer price image.

\section{Store brands and retailer loyalty}

The ability of store brands to build retailer brand has direct relevance to loyalty, either with regard to the store or to the retailer as a chain, by which we include all stores with the same brand name. Corstjens and Lal (2000) have analytically demonstrated that store brands can only generate retail differentiation, store loyalty and store profitability if the quality of the store brand is sufficiently high. However, these major theoretical findings have no consensual empirical validation (Ailawadi and Keller, 2004). Using consumer scanner data, Sudhir and Talukdar (2004) observe that store sales decrease and - simultaneously - that store profitability increases when store brands have a high level of penetration across a customer base. Ailawadi and Harlam (2004) found that heavy buyers of store brands buy less from a retailer than moderate buyers of store brands do. These results are mixed and are also embedded in the North-American market, where store brands are less mature and possibly less sophisticated than in Europe. More recently, based on Dutch household-level data, Ailawadi et al. (2008) found a positive relationship between store brand share and wallet share: higher store brand share increases wallet share and greater wallet share increases store 
brand share. Binninger (2008) also showed a positive relationship between store brands' satisfaction and store loyalty, mitigated by the attitude towards store brands. From these results, we follow Corstjens and Lal (2000) by suggesting that the quality of store brands in Europe is now high enough for store brands' image to contribute positively to retailer loyalty, at the chain level. We further assume here that store brands influence retailer loyalty in line with the three dimensions we propose (cf. Figure 1).

H2 - There is a positive association between store brand and retailer loyalty on all dimensions of the store brand image:

H2(a) - price dimension;

H2(b) - supply dimension;

H2(c) - values dimension.

For instance, H2(a) means that a good price image for the store brand enhances retailer loyalty, whereas a poor price image for the store brand decreases retailer loyalty.

\section{Research Design}

Sampling

To test the conceptual model, a quantitative survey was performed with customers from three major French retailers. We only selected retailers that shared the same format and we excluded chains with smaller stores: three hypermarket chains, namely Carrefour, Auchan and E.Leclerc, were chosen. The sample consists of 322 valid questionnaires. The sample group is made up of 208 women and 113 men. All participants were habitual shoppers at one of the three retailers, as they did the majority of their shopping in one of these stores (Table 1). We focused only on basic store brands, excluding premium store brands and discount store brands, so as to emphasise comparable products across the three chains. We checked the consumers' familiarity with store brands: all the respondents clearly identified store brands and had tried store brands at least once. 
Table 1. - Sample characteristics

\begin{tabular}{|c|c|c|c|}
\hline \multicolumn{2}{|c|}{ Descriptive variables } & \multirow{2}{*}{$\begin{array}{c}\text { Qualitative study } \\
\text { Sample \# 1 } \\
\begin{array}{c}\mathbf{2 0 0 6} \\
(\mathbf{n}=\mathbf{1 3 8})\end{array} \\
58(42 \%) \\
\end{array}$} & \multirow{2}{*}{$\begin{array}{c}\text { Quantitative study } \\
\text { Sample \# 2 } \\
\mathbf{2 0 0 9} \\
(\mathbf{n}=\mathbf{3 2 2}) \\
113(35 \%)\end{array}$} \\
\hline & Men & & \\
\hline Gender & Women & $80(58 \%)$ & $208(65 \%)$ \\
\hline \multirow{4}{*}{ Age } & $18-24$ & $48(35 \%)$ & $77(24 \%)$ \\
\hline & $25-39$ & $49(35 \%)$ & $129(40 \%)$ \\
\hline & $40-55$ & $25(18 \%)$ & $88(27 \%)$ \\
\hline & $>55$ & $16(12 \%)$ & $28(9 \%)$ \\
\hline \multirow{5}{*}{$\begin{array}{l}\text { Most } \\
\text { frequent } \\
\text { retailer }\end{array}$} & Auchan (HM) & $45(33 \%)$ & $119(37 \%)$ \\
\hline & E. Leclerc (HM) & $37(27 \%)$ & $90(28 \%)$ \\
\hline & Carrefour (HM) & $35(25 \%)$ & $113(35 \%)$ \\
\hline & Casino (SM) & $7(5 \%)$ & 1 \\
\hline & Champion (SM) & $14(10 \%)$ & 1 \\
\hline
\end{tabular}

HM =hypermarket $; S M=$ supermarket

\section{Measure}

Retailer brand image. Existing scales focus on store image rather than on the retailer's brand image. Ailawadi and Keller (2004) and Burt and Davies (2010) point out that even academic studies on retailer branding per se take "store image as a proxy for the retailer brand image". We therefore developed a scale specifically for the retailer brand image that was based on our literature review and qualitative survey. The 12 items listed explicitly mention the retailer as a brand, as in for instance 'Retailer X (brand name) provides a large array of products' or 'Retailer X (brand name) is committed to sustainable development'. Items include the retailer's low prices, special offers, value for money, quality and variety of assortment, store atmosphere, innovation, proximity, convenience, protection of buying power, commitment to sustainable development and protection of the environment (Table 2). Five-point Likert scales were used to measure the consumers' agreement with the retailers' brand statements.

Store brands' image. Following Collins-Dodd and Lindley (2003), we decided to duplicate the retailer brand scale for the store brands. The items previously cited for the retailer brand become, for example, 'The store brand X proposes a large array of products' and 'The store brand $\mathrm{X}$ is committed to sustainable development'. Thus, the items we used to measure the image of the store brands were very similar to those employed to measure the retailer's brand image. We used principal components analyses and structural equation modeling to develop and to confirm these scales (see Table 2). 
Retailer loyalty. Retailer loyalty is measured by two items on a five-point Likert scale: 'I do most of my shopping in the stores of retailer X' and 'I am loyal to retailer X'.

\section{Testing of the model}

The model relates the three dimensions of the store brands' image to the three dimensions of retailer brand image. The dimensions of store brand image are also related to retailer loyalty (see Figure 2). Structural equation modeling was used to test the model.

\section{Results}

Validation of the scale. Factor analyses conducted on the scales of image perception show that retailer brand image and the store brands image can be broken down into three dimensions, as postulated (Table 2). The first dimension includes values shared by both the retailer and the store brands: commitment to sustainable development, protection of the environment, protection of buying power, proximity and convenience. The second dimension refers to the supply side: variety, quality of the assortment, pleasant stores for the retailer, quality, product variety and appealing packaging of the store brands. The third dimension is related to the retailer's prices and store brand prices (low prices and value for money). After the confirmatory analysis, two items were discarded in both the retailer and the store brand scales.

Table 2. - Principal Components Analysis

\begin{tabular}{|c|c|c|c|}
\hline Items & \multicolumn{3}{|c|}{ Components } \\
\hline $\begin{array}{l}\text { Retailer brand image } \\
(\text { Explained Var. }=71,6 \% ; \mathrm{KMO}=0,809 ; \text { Bartlett }=1455 ; d f=45 ; \alpha= \\
0,001)\end{array}$ & $\begin{array}{l}\text { Values } \\
(\alpha=0.86)\end{array}$ & $\begin{array}{c}\text { Supply } \\
(\alpha=0.73)\end{array}$ & $\begin{array}{c}\text { Price } \\
(\alpha=0.80)\end{array}$ \\
\hline $\begin{array}{l}\text { RV1- The retailer X is committed to sustainable development. } \\
\text { RV2- The retailer X is concerned with the environment. } \\
\text { RV3- The retailer X fights for the customers' interests. } \\
\text { RV4- The retailer X is close to customers. } \\
\text { RV5- The retailer X is convenient. }\end{array}$ & $\begin{array}{l}0.865 \\
0.834 \\
0.759 \\
0.730 \\
0.653\end{array}$ & & \\
\hline $\begin{array}{l}\text { RS1- The retailer X provides a large array of products. } \\
\text { RS2- The retailer X offers good quality products. } \\
\text { RS3- The retailer X has pleasant stores. }\end{array}$ & & $\begin{array}{l}0.896 \\
0.766 \\
0.696\end{array}$ & \\
\hline $\begin{array}{l}\text { RP1- The retailer } X \text { has low prices every day. } \\
\text { RP2- The retailer X offers good value for money. }\end{array}$ & & & $\begin{array}{l}0.914 \\
0.835\end{array}$ \\
\hline
\end{tabular}




\begin{tabular}{|c|c|c|c|}
\hline $\begin{array}{l}\text { Store brands image } \\
(\text { Explained Var. }=69,1 \% ; \mathrm{KMO}=0,847 ; \text { Bartlett }=1626 ; d f=45 ; \alpha= \\
0,001)\end{array}$ & $\begin{array}{c}\text { Values } \\
(\alpha=0.90)\end{array}$ & $\begin{array}{l}\text { Supply } \\
(\alpha=0.69)\end{array}$ & $\begin{array}{c}\text { Price } \\
(\alpha=0.73)\end{array}$ \\
\hline $\begin{array}{l}\text { SBV1- The store brand } X \text { is committed to sustainable } \\
\text { development. } \\
\text { SBV2- The store brand X is concerned with the environment. } \\
\text { SBV3- The store brand X fights for the customers' interests. } \\
\text { SBV4- The store brand X is close to customers. } \\
\text { SBV5- The store brand X is convenient. }\end{array}$ & $\begin{array}{l}0.927 \\
0.908 \\
0.854 \\
0.754 \\
0.724\end{array}$ & & \\
\hline $\begin{array}{l}\text { SBS1- The store brand } X \text { offers good quality. } \\
\text { SBS2- The store brand X provides a large array of products. } \\
\text { SBS3- The store brand X has an appealing packaging. }\end{array}$ & & $\begin{array}{l}0.876 \\
0.789 \\
0.674\end{array}$ & \\
\hline $\begin{array}{l}\text { SBP1- The store brand X has low prices every day. } \\
\text { SBP2- The store brand X offers good value for money. }\end{array}$ & & & $\begin{array}{l}0.963 \\
0.735 \\
\end{array}$ \\
\hline
\end{tabular}

Model validation. The model was fitted against the data with AMOS 5. We obtained the following results: $\chi^{2}=449, \mathrm{df}=194$ for a parcimony indicator of 2.34 that is congruent with the recommendations of Pedhazur and Pedhazur-Schmelkin (1991). RMSEA $=0.064$ and GFI $=0.873$ indicate that the model fits the data well (see Figure 2 and Table 3 ).

Table 3. - Confirmatory factor analysis

\begin{tabular}{|c|c|c|c|}
\hline Items & & Componen & \\
\hline Retailer brand image & Loadings & \begin{tabular}{|c|}
$\begin{array}{c}\text { Joreskog's } \\
\text { rho }\end{array}$ \\
\end{tabular} & AVE* \\
\hline $\begin{array}{l}\text { RV1- The retailer X is committed to sustainable development. } \\
\text { RV2- The retailer X is concerned with the environment. } \\
\text { RV3- The retailer X fights for the customers' interests. } \\
\text { RV4- The retailer X is close to customers. } \\
\text { RV5- The retailer X is convenient. }\end{array}$ & $\begin{array}{l}0.88 \\
0.84 \\
0.77 \\
0.76 \\
0.70 \\
\end{array}$ & 0.89 & 0.63 \\
\hline $\begin{array}{l}\text { RS1- The retailer X provides a large array of products. } \\
\text { RS2- The retailer X offers good quality products. } \\
\text { RS3- The retailer X has pleasant stores. }\end{array}$ & $\begin{array}{l}0.70 \\
0.85 \\
0.49 \\
\end{array}$ & 0.73 & 0.48 \\
\hline $\begin{array}{l}\text { RP1- The retailer X has low prices every day. } \\
\text { RP2- The retailer X offers good value for money. }\end{array}$ & $\begin{array}{l}0.79 \\
0.76 \\
\end{array}$ & 0.75 & 0.60 \\
\hline Store brands image & Loadings & \begin{tabular}{|c|c|}
$\begin{array}{c}\text { Joreskog's } \\
\text { rho }\end{array}$ \\
\end{tabular} & AVE \\
\hline $\begin{array}{l}\text { SBV1- The store brand } X \text { is committed to sustainable } \\
\text { development. } \\
\text { SBV2- The store brand X is concerned with the environment. } \\
\text { SBV3- The store brand X fights for the customers' interests. } \\
\text { SBV4- The store brand X is close to customers. } \\
\text { SBV5- The store brand X is convenient. }\end{array}$ & $\begin{array}{l}0.92 \\
0.91 \\
0.83 \\
0.79 \\
0.71 \\
\end{array}$ & 0.92 & 0.70 \\
\hline $\begin{array}{l}\text { SBS1- The store brand X offers good quality. } \\
\text { SBS2- The store brand X provides a large array of products. } \\
\text { SBS3- The store brand X has an appealing packaging. }\end{array}$ & $\begin{array}{l}0,73 \\
0.84 \\
0.65 \\
\end{array}$ & 0.79 & 0.55 \\
\hline $\begin{array}{l}\text { SBP1- The store brand } X \text { has low prices every day. } \\
\text { SBP2- The store brand X offers good value for money. }\end{array}$ & $\begin{array}{l}0.75 \\
0.82\end{array}$ & 0.77 & 0.62 \\
\hline
\end{tabular}


$*$ AVE $=$ Average Variance Extracted

Evidence for convergent validity was established in accordance with the Fornell and Larcker procedure (1981). When the AVE is above 0.5, the variance of a construct is better explained by the items which measure it than by error. For each factor, the average variance extracted was above 0.5, except for 'Retailer Supply'.

To establish discriminant validity, we followed the method suggested by Fornell and Larcker, (1981). Discriminating validity is confirmed if the AVE of a dimension is superior to the square of every correlation between itself and other latent concepts. We were unable to calculate this for the Retailer Brand Image. Indeed, the dimensions of Retailer Image were considered as dependent latent variables in the model, so we did not have the correlations between factors at our disposal. Discriminant validity is established for the three factors of the store brand image.

Table 4. - Discriminant validity of the Store Brand Image

\begin{tabular}{l|lll}
\hline Phi-Square & Values & Supply & Price \\
\hline Values & - & & \\
Supply & 0.36 & - & \\
Price & 0.29 & 0.45 & - \\
\hline AVE & 0.70 & 0.55 & 0.62 \\
\hline
\end{tabular}


Figure 2. - The contribution of store brands to the retailer brand image

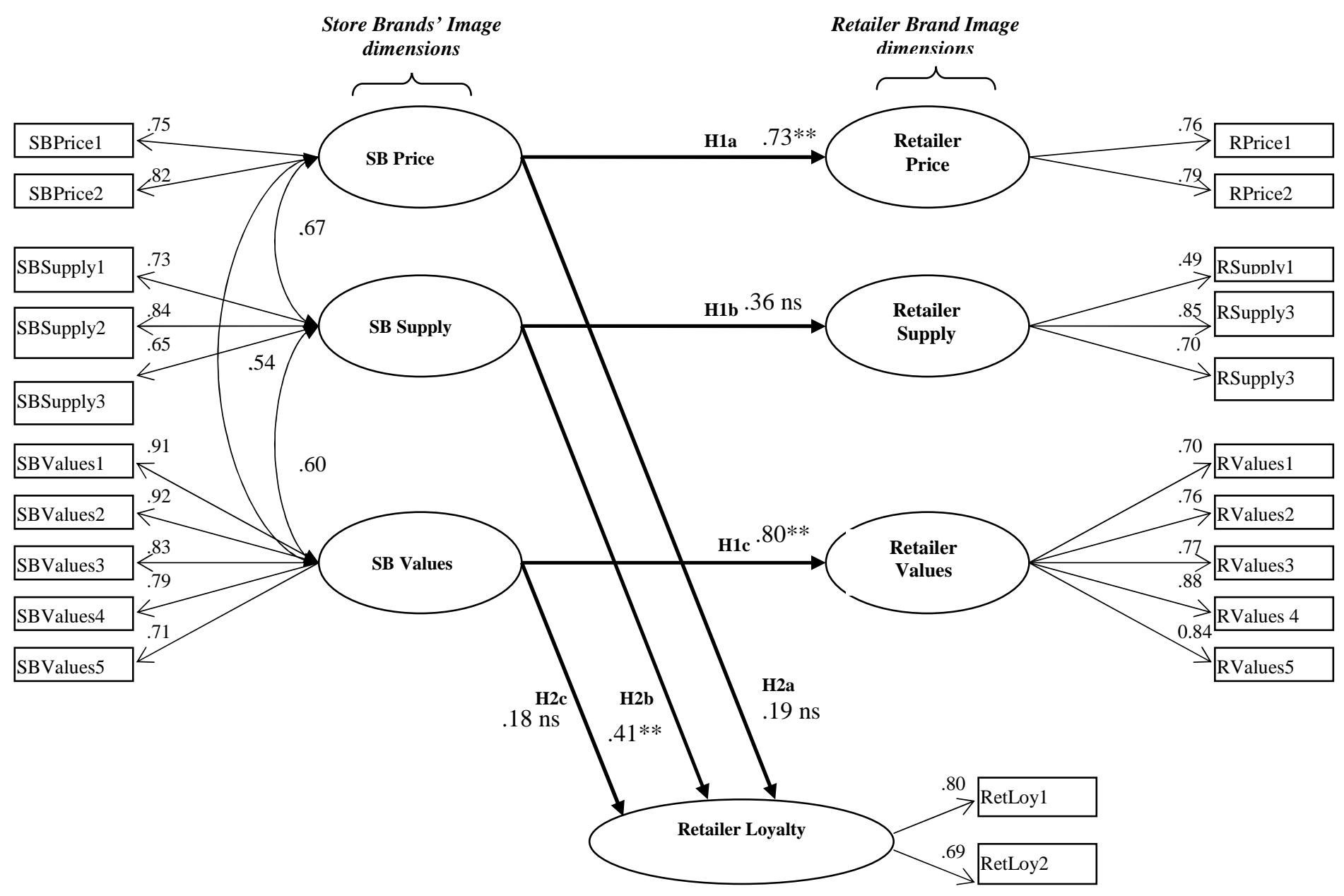


The results confirm the existence of a reciprocity effect that transfers from the store brands to the retailer brand (See Figure 2). The effect appears to be significant in two dimensions: the price dimension of store brands is positively related to that of the retailer brand image; and the store brands' values are positively related to the retailer's values. H1a and H1b are supported. The supply image of store brands, however, has no significant effect on the retailer supply image but it is positively related to retailer loyalty.

The price and values dimensions of the store brands' image have no significant effect on retailer loyalty. Thus, there is no support for $\mathrm{H} 2 \mathrm{a}$ and $\mathrm{H} 2 \mathrm{c}$. Only $\mathrm{H} 2 \mathrm{~b}$ is supported.

\section{Discussion and implications}

This research shows that store brands can influence the brand image of the retailer. This finding will be of great importance to retailers who have been actively developing store brand programs for the last ten years.

Theoretical implications. Our results clearly show that the link between the store brand and the retail brand is not limited to a downward relationship. Whereas previous literature has demonstrated that the retail brand provides backing to the store brand (Richardson et al 1996, Semeinj et al 2004, Vahie and Paswan, 2006), we empirically validate a reciprocity effect from the store brand up to the retail brand. This image transfer from the store brand to the retailer brand can be likened to the positive link identified in the brand extension literature between the extension and the parent brand.

Relying on a qualitative study and previous literature on store image, we first suggest that the image transfer operates according to three dimensions: a price dimension (including price level and value for money), a supply dimension (including range, product quality and packaging) and a values dimension (including environmental concerns, protection of the customers' interests, commitment to sustainable development, proximity and convenience). The quantitative study validates an image transfer within two of the three hypothesized dimensions: price and values. Store brands associated with lower price and good value for money help improve the competitive image of the retailer. Moreover, when consumers notice that store brands are committed to respecting the environment or satisfying their needs, the retailer's image is improved. Nevertheless, an image transfer through the supply dimension has not been validated. An attractive store brand supply (characterized by good quality products, variety and appealing packaging) seems to have no significant effect on the retailer brand image. This might be first explained by the positioning of store brands in Europe. By 
increasing the quality of their store brands, European retailers have progressively closed the quality gap between store brands and national brands (Kumar and Steenkamp, 2007; Steenkamp et al, 2010). Product quality may not be as salient as price when consumers evaluate store brands. Moreover, the reduction in quality gap has not been accompanied by a smaller price gap. This confers on store brands a unique advantage over national brands in terms of value of money, especially in the context of economic crisis.

We also found that store brand image contributes to retailer loyalty. Interestingly, only the supply dimension of store brands' image is positively related to retailer loyalty, but the same dimension appears to have no effect on retailer brand image. It is not surprising that customers are loyal to a retailer when the supply appeals to them. However, if the supply is not attractive enough to customers, then price and the values espoused by store brands may not be enough to keep them loyal. This result suggests that there is a threshold for store brands in terms of quality and in the variety of supply required for customers to be loyal to the retailer. We obtain this result in a European context where consumers are very familiar with store brands and their market share is high. This result is an additional empirical validation of the research even though its results are not consensual.

Practical implications. This research sheds light on the contribution of store brands to retailer brand image. It enables practitioners to have a clearer understanding of the role that store brands play in retail strategy. The image transfer from store brands to the retailer's brand confirms that integrating store brands is the interests of chain managers, especially when they are deciding their communication strategies.

Our paper highlights the dimensions that retailers should focus on to promote their store brands. Traditional characteristics associated with store brands such as low price and value for money seem efficient in improving the price positioning of the retailer. This is crucial in a context where consumers are price sensitive and retailers compete on price. More surprisingly, unexpected factors related to store brands' values also seem to enhance retail brand equity. The five components we identified in the values dimension give indications of how to differentiate a given retailer from its competitors. Aligning a store brands' values with its own image will help retailers build a richer positioning than just low pricing. For instance, the perceived proximity between store brands and customers is underexploited by retailers in their communications. We suggest here that store brands can help retailers express or enhance their brand identity, especially retailers whose brand identity is weak. 
Our results are more ambiguous when it comes to quality. On the one hand, we show that store brand quality positively influences retailer loyalty; but, on the other hand, store brand quality does not significantly impact the retailer brand image. Is it then relevant for retailers to invest in innovative and quality store brand programs? The answer is, only if they are profitable. As shown by Kumar et al (2006), Kumar and Shah (2004) and Reinartz and Kumar (2002), the quest for loyalty should not be disconnected from long-term profitability. Product quality, variety and attractive packaging for store brands may lead customers to be loyal to a chain, but retailers must weigh up expected benefits against the cost of creating sophisticated store brands. Kumar and Steenkamp (2007) provide retailers with a "get-out" from the pitfall of developing new lines of store brands that go beyond copycat product creation to requiring marketing costs as high as those needed to manufacture a new brand.

Further research. We limited our research to standard mid-range store brands. Many retailers have segmented their store brand range into three tiers: generic store brands with a discount positioning, standard store brands that copy the quality and look of the leading manufacturers' brands, and premium store brands with high value-added products (Ailawadi and Keller, 2004). Future research is needed to compare the respective contribution of store brands vs. premium store brands, and to compare generic products to the retailer image. In the same way, the impact of thematic store brands (such as organic store brands or store brands for children) on the retailer image should be explored.

Our study was conducted across chains and across product categories. In further research, image transfer could be investigated retailer by retailer. Moreover, it would be interesting to test the indirect effect of SB on retailer loyalty mediated by their respective retailer brand (i.e., price, supply and value respectively) ${ }^{5}$. That would mean increasing the sample size for each retail chain.

Our research could also be replicated by isolating product categories, in order to fuel research into store brand extensions across categories. We also suggest investigating image transfer across time from store brand to retailer brand, in a longitudinal study. Whereas European grocery retailers have developed store brands in almost all food product categories, there is still an opportunity for launching specific store brands in the whole retailing sector (clothing, toys, home improvement product and services, etc.). In specific cases, it would be interesting to compare the image of the retailer before and after the introduction of new store brands.

\footnotetext{
${ }^{5}$ We thank on of the reviewer for this suggestion.
} 
Similar research could, finally, be replicated for hard discounters such as Aldi or Lidl, which have massively reintroduced national brands into their assortment, whereas in the past they only promoted their own discount products. It would be interesting to examine whether and how national brands influence their image, from a retail branding perspective. 


\section{References}

Aaker D. A. and Keller. K. L. (1990), "Consumer evaluation of brand extensions", Journal of Marketing, Vol. 54 No. 1, pp. 27-41.

Ailawadi, K. and Harlam, B., (2004), "An empirical analysis of the determinants of retail margins: the role of store brands", Journal of Marketing, Vol. 68 No. 1, pp. 147-165.

Ailawadi, K. and Keller, K. L. (2004), "Understanding retail branding: conceptual insights and research priorities", Journal of Retailing, Vol. 80 No. 4, pp. 331-342.

Ailawadi, K., Pauwels, K. and Steenkamp, J.-B., (2008), "Private-Label Use and Store Loyalty", Journal of Marketing, Vol.72 No. 6, pp. 19-30.

Binninger, A.-S. (2008), "Exploring the relationships between retail brands and consumer store loyalty", International Journal of Retail and Distribution Management, Vol.36 No. 2, pp. 94-110.

Birtwistle G., Clarke I. and Freathy P. (1999), "Store image in the UK fashion sector: consumer versus retailer perceptions", The International Review of Retail, Distribution and Consumer Research, Vol. 9 No. 1, pp. 1-16

Boush D., Shipp S., Loken B., Gencturk E., Crockett S., Kennedy E., Minshall B., Misurell D., Rochford L. and Strobel J. (1987), "Affect generalization to similar and dissimilar brand extensions", Psychology \& Marketing, Vol.4 No. 3, pp. 225-237.

Burt, S.L. and Sparks, L. (2002), "Branding Experiences: Corporate Branding in Retail", Corporate Reputation Review, Vol.5 Nos 2/3, pp. 193-213.

Burt, S.L. and Davies, K. (2010), "From the retail brand to the retail-er as a brand: themes and issues in retail branding research", International Journal of Retail and Distribution Management, Vol.38 Nos 11/12, pp. 865-878.

Chowdhury J., Reardon J. and Srivastava R. (1998), "Alternative modes of measuring store image: an empirical assessment of structured versus unstructured measures", Journal of Marketing Theory and Practice, Vol. 6 No. 2, pp. 72-86.

Collins-Dodd, C. and Lindley T. (2003), "Store brands and retail differentiation: the influence of store image and store brand attitude on store brand own perceptions", Journal of Retailing and Consumer Services, Vol. 10 No. 4, pp. 354-352.

Corstjens, M. and Lal, R. (2000), "Building Store Loyalty Through Store Brands", Journal of Marketing Research, Vol. 37 No. 3, pp. 281-291.

Dimitriadis, S. (1993), "Brand extension and Retail Brand Extension: conceptual framework and managerial implications", Recherche et Applications en Marketing, Vol. 8 No. 3, pp. 21-44.

Fornell C. and Larcker D.F. (1981), Evaluating structural equation models with unobservable variables and measurement error, Journal of Marketing Research, 18, 1, pp. 39-50.

Gupta S. and Pirsh J. (2008), "The influence of retailer's corporate social responsibility program on re-conceptualizing store image", Journal of Retailing and Consumer Services, Vol. 15 No. 6, pp. 516-526.

Hoch, S.J. and Banerji, S. (1993), "When do private labels succeed?", Sloan Management Review, Vol. 17 No. 5, pp. 368-89.

Jacoby J. and Mazursky D. (1984), "Linking brand and retailer images: do the potential risks outweigh the potential benefits?", Journal of Retailing, Vol. 60 No 2, pp. 105-122.

Keller K. L. and Aaker D. A. (1992), "The effects of sequential introduction of brand extensions", Journal of Marketing Research, Vol. 29 No. 1, pp. 35-50.

Kumar, N. and Steenkamp, J.-B.E.M. (2007), Private Label Strategy: How to meet the Store Brand Challenge, Harvard Business School Press, Boston, MA.

Kumar, V and Shah D. (2004), "Building and sustaining profitable customer loyalty for the $21^{\text {st }}$ century", Journal of Retailing, Vol. 80, pp. 317-330. 
Kumar, V, Shah, D and Venkatesan, R (2006), "Managing retailer profitability - one customer at a time!", Journal of Retailing, Vol. 82, pp. 277-294.

Luijten, T. and Reijnders, W. (2009), "The development of store brands and the store as a brand in supermarkets in the Netherlands", International Review of Retail, Distribution \& Consumer Research, Vol. 19 No. 1, pp. 45-58.

Martenson, R. (2007), "Corporate Brand Image, satisfaction and store loyalty: a study of the store as a brand, store brands and manufacturer brands", International Journal of Retail and Distribution Management, Vol 35 No. 7, pp. 544-555.

Mazursky D. and Jacoby J. (1986)," Exploring the development of store images", Journal of Retailing, Vol. 62 No. 2, pp. 145-165.

McInnis D. and Nakamoto K. (1990), "Examining factors that influence the perceived goodness of brand extensions", Working Paper, University of Arizona, Tucson.

Park C. W., Mc Carthy M. S. and Milberg S. J. (1993), "The effects of direct and associative brand extension strategies on consumer response to brand extensions", in Mc Alister L. and Rothschild, M.L. (Eds.), Advances in Consumer Research, Provo, UT, Association for Consumer Research, Vol. 20, pp. 28-33.

Park C., Milberg S. and Lawson R. (1991), "Evaluation of brand extensions: the role of product feature similarity and brand concept consistency", Journal of Consumer Research, Vol. 18 No. 3, pp. 185-183.

Pettijohn, L., D. Mellott and C. Pettijohn (1992), "The relationship between retailer image and brand image", Psychology and Marketing, Vol. 9 No. 4, pp. 311-328.

Reinartz, W. and Kumar, V. (2002), "The Mismanagement of customer loyalty", Harvard Business Review, Vol. 80, No 7, pp. 86.

Richardson T., Jain A. and Dick A. (1996), "The influence of store aesthetics on the evaluation of private label brands", Journal of Product and Brand Management, Vol. 5 No. 1, pp. 19-28

Semeijn, J., A. van Rieb and Ambrosini A. (2004), "Consumer evaluations of store brands: effects of store image and product attributes", Journal of Retailing \& Consumer Services, Vol. 11 No. 4, pp. 247-259.

Scott-Morton, F. and Zettelmeyer, F. (2004), "The strategic positioning of store brands in retailer-manufacturer negotiations", Review of Industrial Organization, Vol. 24 No. 2, pp. 161-194.

Shwu-Ing, W. and Jui-Ho, C. (2010), "The influence of store image, store satisfaction and store loyalty on store brand extension acceptance: evidence from Taiwanese 3C chain store", Journal of International Marketing \& Marketing Research, Vol. 35 No. 2, pp. 91-110.

Steenkamp, J.B.E.M., Koll, O. and Geyskens, I. (2004), Understanding the drivers of private labels success: a western European perspective 2004, AiMark, Tilburg University, Europanel GfK panel Services Benelux, Dongen, The Netherlands.

Steenkamp, J.B.E.M., Van Heerde, H., and Geyskens, I. (2010),'What makes consumers willing to pay a price premium for national brands over private labels?", Journal of Marketing Research, Vol. XLVII, pp. 1011-1024.

Sudhir, K. and Talukdar, D. (2004), "Do store brand patronage improve store patronage", Review of Industrial Organization, Vol 24 No. 2, pp. 143-160.

Tauber E. M. (1981), "Brand franchise extension: new product benefits from existing brand names", Business Horizons, Vol. 24 No. 2, pp. 36-41.

Vahie, A. and Paswan, A. (2006), "Private label Brand image: its relationship with store image and national brand", International Journal of Retail and Distribution Management, Vol. 34 No. 1, pp. 67-84. 